\title{
万年時計の機構解明*
}

(第 2 報, 動力部)

\author{
羽藤 武宏*1, 鈴木一義*2, 冨井洋一*3 \\ 吉田充 伸*1, 横田泰 宏*1, 久保田 裕二*4
}

\section{Mechanism of "Man-nen dokei", a Historic Perpetual Chronometer (2nd Report, Power Supply)}

\author{
Takehiro HATO*5, Kazuyoshi SUZUKI, Yoichi TOMII, \\ Mitsunobu YOSHIDA, Yasuhiro YOKOTA and Yuji KUBOTA \\ ${ }^{* 5}$ Corporate R \& D Center, Toshiba Corporation, \\ 1 Komukai-Toshiba-cho, Saiwai-ku, Kawasaki-shi, Kanagawa, 212-8582 Japan
}

\begin{abstract}
The "Man-nen dokei", which is a historic perpetual chronometer, was made in 1851 by Hisashige Tanaka, who founded the predecessor of Toshiba Corporation. It has six multi-functional clock faces and a celestial globe. It is said that it runs for almost a year with just a single winding. Mannen dokei was disassembled and restored in a national project. We investigated on the mechanism of Man-nen dokei in cooperation with this project. In this paper, we report on the mechanism of the power supply. As a result, from mechanism constitution of the power supply, we confirmed that maximum continual movable days of Man-nen dokei were approximately 225 days. But from the fusee steps and the double spring composition, it is thought that Hisashige's goal was to make it move for 1 year continually. The spring that generates the huge torque became necessary to make it move for 1 year, but it is assumed that the spring were wound just a little due to strength poverty of the wooden frame. Moreover, we think the composition of one fusee is a reasonable design to obtain necessary torque continuous operation with stability for 1 year, and the reason why Hisashige used composition of two fusees still remains to be unclear.
\end{abstract}

Key Words : Mechanism, History of Engineering, Precision Instrument, Mechanical Clock, Power Supply, Torque Equalization, Spring, Fusee

\section{1. まえがき}

万年時計（正式名称 : 万年自鳴鐘）は，東芝の創業 者「からくり儀右衛門」こと田中久重が 1851 年に製作 した機械式時計である（図 1）。この時計は, 東洋の 自然界に合わせた生活に西洋の技術を融合させ，複雑 な機構により様々な時表示機能を実現したものであり， 和時計の最高傑作と言われている. 2005 年に愛知県で 開催された愛・地球博でも紹介され，2006 年 6 月に国 の重要文化財に指定された.この万年時計は, 高さ約 $60 \mathrm{~cm}$ (置台除く), 重さ約 $38 \mathrm{~kg}$ あり, 1000 点を超え る部品で構成されている. 天頂部には，太陽と月の運 行を示す「天球儀」を有し，その下の六面体の各面に はそれぞれ機能が異なる 6 種類の時表示部を有する

* 原稿受付 2006 年 9 月 15 日。

*1 正員, (株) 東芝研究開発センター(- 212-8582 川崎市幸区 小向東芝町 1 ).

*2 国立科学博物館理工学研究部 (- 169-0073 東京都新宿区百 人町 3-23-1).

*3 京都大学大学院エネルギー科学研究科(画606-8317 京都市 左京区吉田本町).

*4 正員, フェロー, (株) 東芝研究開発センター.

E-mail : takehiro.hato@ toshiba.co.jp
(1)(3). 時表示部の下には, 六本脚の台座があり, その 中に時打用の鐘が配置されている.ささらに，その下の 六角台座（直径約 $65 \mathrm{~cm}$ ) には, 各面異なった七宝絵図 が描かれており，この台座の中に万年時計の動力とな るゼンマイが 4 つ納められている(4).

ゼンマイから時計表示部や天球儀への動力伝達図を 図 2 に示す. ゼンマイは 2 つで 1 組の動力を構成して おり，時方用と打方用の 2 組の動力を有する. ゼンマ イで発生した動力が, 円錐形で描かれているフュジー (均力車) を介して，時方と打方の一番車にそれぞれ 伝わり，そこから各駆動部に動力が伝達され万年時計 としての動作を実現している.

万年時計は，ゼンマイを 1 度巻くと 1 年連続動作し たと言われている. 万年時計の広告や文献にもとのよ うな記述が見られる ${ }^{(5),(6)}$.このスペックを実現するに は, 動力部構成がポイントとなる. 当時の時計の動力 としては，ゼンマイとフュジ一の構成が一般的に用い られていた. ゼンマイは 1500 年頃に発明され, フュジ 一機構は 1525 年頃に発明された. その後, フランスや 


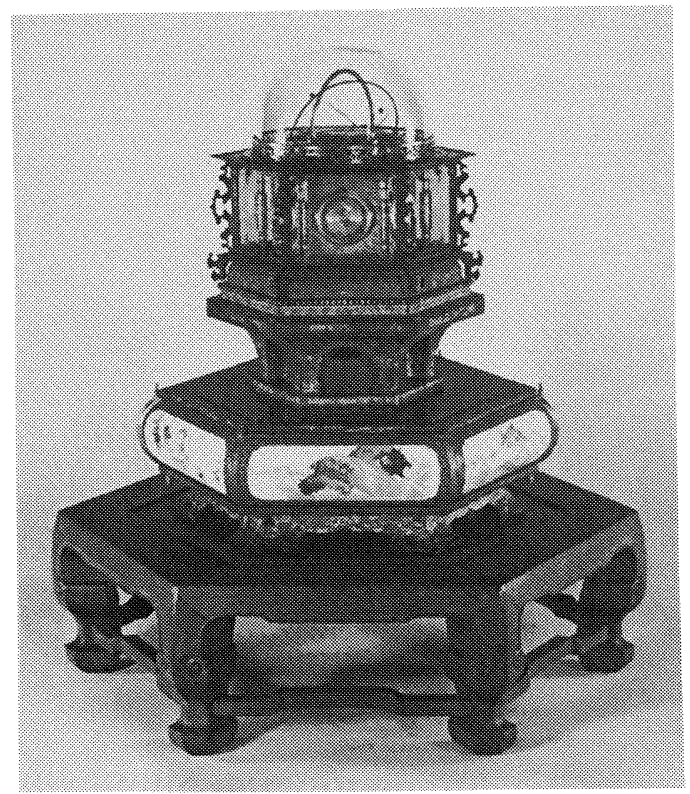

Fig. 1 Man-nen dokei

イギリスなどで時計の動力として用いられ， 1600 1800 年には懐中時計に用いられた。また，1700 年代にはクロノメータが航海で使用され，フュジ一機 構の技術発展に繋がった(7)。このような背景から，万 年時計が製作された 1850 年頃には, ゼンマイ・フュジ 一機構の技術は，西洋ではある程度普及していたと考 えられる. 弓曳童子や須弥山儀など万年時計以前の田 中久重の作品を見てもゼンマイ・フュジ一構成の動力 が用いられている( ${ }^{(8)}$. 万年時計でもゼンマイ・フュジ 一構成が動力として用いられているが，その構成は 2 ゼンマイ・2 フュジーとなっており，このような構成 は西洋の機械式時計や久重の他の作品でも見られず, 極めて珍しい.

今回, 文部科学省研究費補助金特定領域研究「我が 国の科学技術黎明期資料の体系化に関する調查研究」

（通称：江戸のモノづくり）の一環として，万年時計 の分解・調査・復元・複製作業が行われた.これまで も, 分解調查は何回か行われているが(9), 機構動作を 詳細に報告している資料はない，特に長時間駆動を実 現するために工夫したと考えられる動力部については, ほとんど記録が残っていない，そこで，本論文では， 今回の分解調查で得られたデータなどを参考に万年時 計の動力部の構造を解明し, 機構について考察を行っ たので，その結果を報告する．

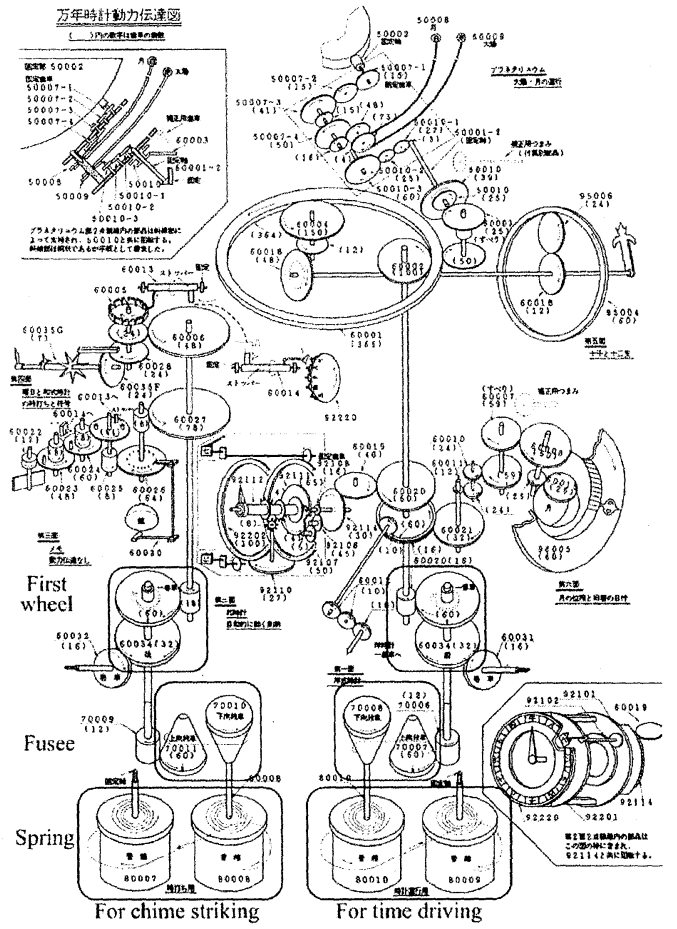

Fig. 2 Schema of power transmission

\section{2. 動力部の構成}

$2 \cdot 1$ 機構の構成 万年時計の動力部の $\mathrm{CG}$ 透視 図を図 3 に, 内部機構の CG 図を図 4 に示寸. 万年時 計の一番下に位置する木製六角台座の中に，香箱に納 められたゼンマイが 4 つ配置されている. 図40よう に2つの香箱をチェーンで接続し, ゼンマイ 2 つで 1 つの動力を構成している. 図 5 のゼンマイ部の写真に 示すように, 1 つの動力につき 1 つのゼンマイの軸が $\mathrm{X}$ 字型の金属板に固定され，もう一方のゼンマイ軸は, 出力軸として上部のフュジー機構に繋がるように長く なっている．香箱は何れも固定されていない．このよ うな構成とすることで，出力軸では， 2 つのゼンマイ の回転数を足し合わせた回転数の出力が得られる. ゼンマイ出力軸は，六脚台座の脚の中を通り，図6に 示すフュジ一機構部に動力を伝えている. ゼンマイ出 力軸には下向きのフュジー（入力側フュジー）が直接 取り付けられてあり，上下反対向きのフュジ一（出力 側フュジー）とチェーンで繋がれ, 出力フュジーの歯 車を介して, 時計動作の駆動源となる一番車まで動力 が伝わるようになっている. つまり, ゼンマイ $2 つ の$ 出力が, フュジー2 つを介して均力化され, それぞれ 時方と打方の動力になっている. ゼンマイは一度解か 


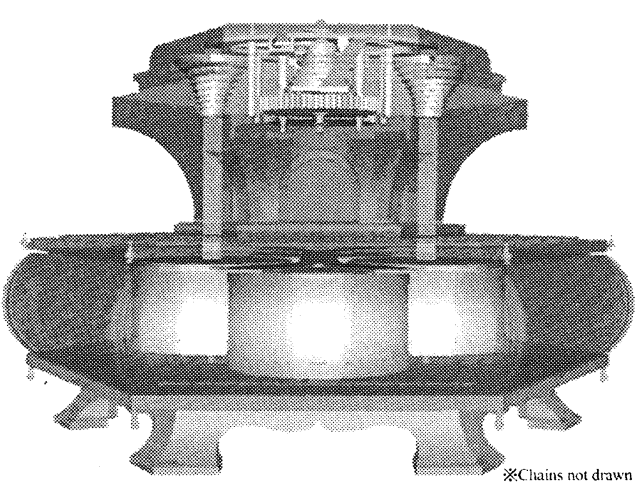

Fig. 3 CG perspective view of power supply

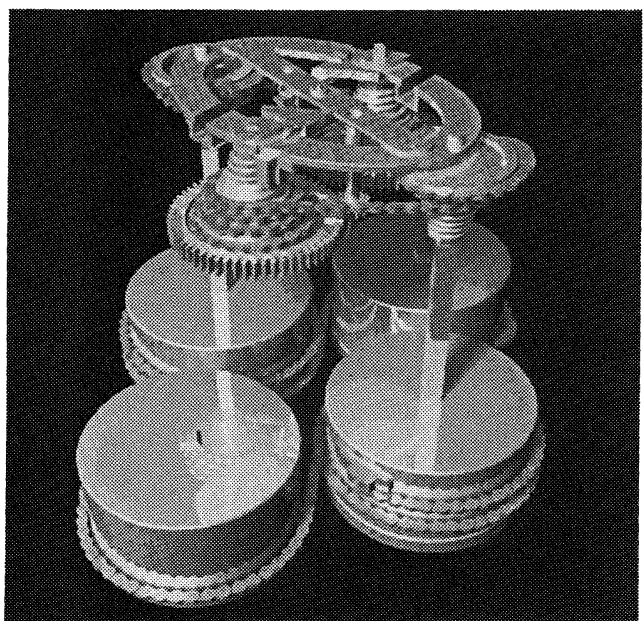

Fig. 4 Internal mechanism CG image of power supply

れると一気に動力を解放してしまうため調速機構が必 要となるが, 時方側の調速は洋時計内の調速機がその 役割を果たしている. 一方, 打方側の調速機構は風切 車であるが, 動くタイミングは和時計に連動しており, 間欠的に動くようになっている.

フュジーは, 図7のように螺旋状の形状をしており， この形状により, ゼンマイをどの程度均力化できるか 決まる. 万年時計のフュジーは，手作りであるため 4 つの形状が微妙に異なる. フュジーの中心とチェーン をフュジ一に止めるために開けられた穴の中心を通る 断面における各段の寸法（直径）を表 1 に示す.

各フュジーの軸は, 楕円状の金属板 (フュジ一受板： Fusee support plate）と台座枠により支持されている. また, 図7のように, 入力側と出力側フュジ一の支持 高さは, 出力側フュジ一の歯車の厚さ分だけずれてお り, 入力側フュジーの下から 2〜3 段目と出力側フュジ 一の一番下の段がチェーンで繋がる.フュジ一受板は

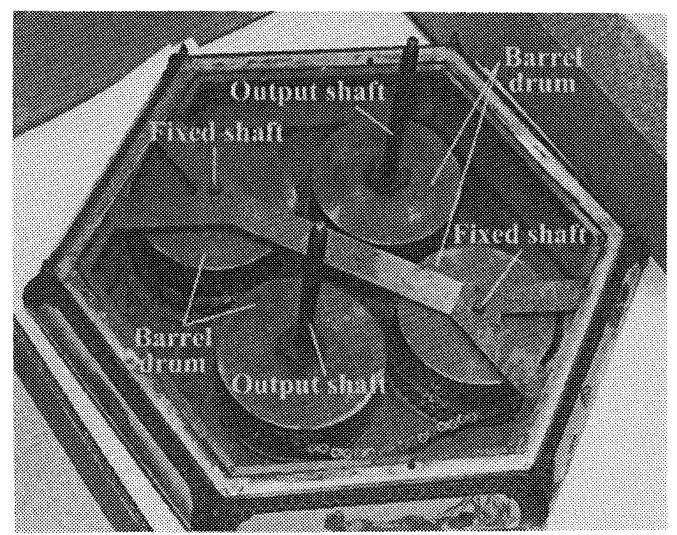

Fig. 5 Spring section of the power supply

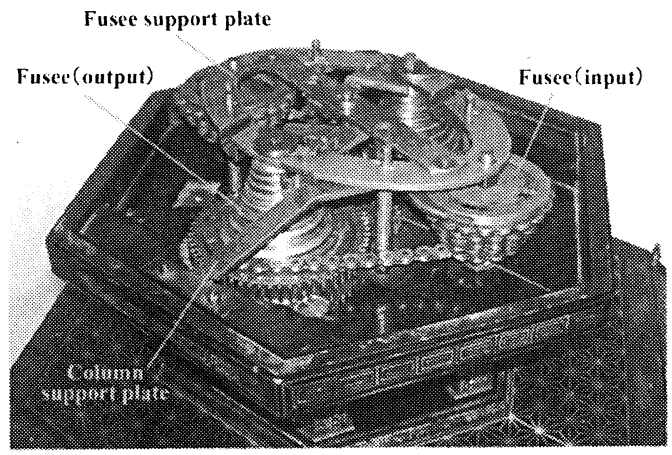

Fig. 6 Fusee mechanism section of the power supply

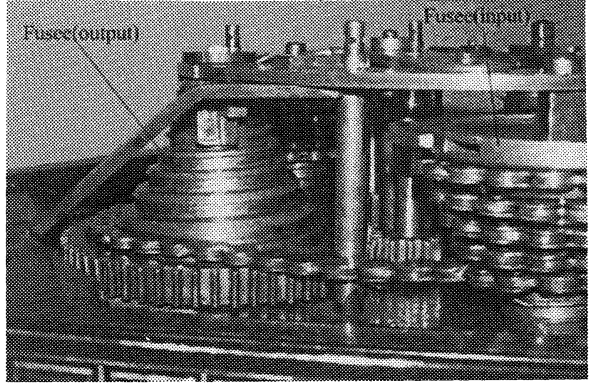

Fig. 7 Fusee

4 本の金属柱によって支持されているが，そのうち 2 本の金属柱には，台座から伸びた斜めの板（柱受板： Column support plate）が接続されている. この柱受板 は，フュジ一受板の回転を防ぐために取り付けられて いるように見える. また, 出力側フュジ一軸の上には 勾玉形状の力ムがついており, レバー形状の部品とで 巻量調節機構を形成している. 巻き量調節機構は, ゼ ンマイのネジの巻き過ぎを防止するための機構であり， 
Table 1 Fusee size data

\begin{tabular}{|c|c|c|c|c|c|}
\hline \multirow[b]{2}{*}{$\begin{array}{l}\text { Fusee } \\
\text { steps }\end{array}$} & \multicolumn{2}{|c|}{$\begin{array}{c}\text { Fusee for } \\
\text { diving clock }\end{array}$} & \multicolumn{2}{|c|}{$\begin{array}{c}\text { Fusee for } \\
\text { striking chimes }\end{array}$} & \multirow[b]{2}{*}{$\begin{array}{l}\text { Average } \\
\text { [mm] }\end{array}$} \\
\hline & $\begin{array}{l}\text { Spring } \\
\text { side } \\
{[\mathrm{mm}]}\end{array}$ & $\begin{array}{l}\text { Output } \\
\text { side } \\
{[\mathrm{mm}]}\end{array}$ & $\begin{array}{l}\text { Spring } \\
\text { side } \\
{[\mathrm{mm}]}\end{array}$ & $\begin{array}{l}\text { Output } \\
\text { side } \\
{[\mathrm{mm}]}\end{array}$ & \\
\hline 1 & 62.3 & 62.5 & 60.7 & 61.0 & 61.6 \\
\hline 2 & 61.6 & 52.7 & 57.0 & 57.0 & 57.1 \\
\hline 3 & 45.7 & 44.9 & 50.7 & 49.7 & 47.8 \\
\hline 4 & 39.1 & 38.5 & 44.2 & 43.4 & 41.3 \\
\hline 5 & 33.8 & 33.1 & 38.1 & 38.9 & 36.0 \\
\hline 6 & 29.5 & 29.3 & 31.9 & 31.5 & 30.6 \\
\hline 7 & 26.3 & 27.5 & 29.3 & 29.1 & 28.1 \\
\hline 8 & 23.7 & 25.7 & 26.9 & 26.5 & 25.7 \\
\hline 9 & 22.3 & 21.0 & 24.3 & 24.7 & 23.1 \\
\hline
\end{tabular}

ゼンマイ・フュジ一機構では一般的に用いられている (7). 万年時計では, 出力側フュジ一が約 6 回転したと きにロックがかかるようになっている．万年時計の動 作スピードを決める洋時計の一番車の回転速度から計 算すると, 出力側フュジーは37.5 日で 1 回転する.こ のことから, 万年時計の機構的な最大連続稼働日数は, 約 225 日であることがわかる.この連続稼動日数は以 前の分解調査で明らかにされているが(9)，今回改めて その理由も含めて確認することができた.これまで言 われていた 1 年連続稼動の日数よりは少ないが，当時 の時計の動作日数が長くて 10 日程度であったので, 当 時としては驚くベきスペックを実現する機構を製作し たことがわかる.

2-2 木伜に作用するカ 図6で示した柱受板は, その取り付け方向と形状から, フュジ一受板の回転を 防ぐ据れ防止構造であると考えられる. そこで，本節 ではフュジ一受板及び木枠（六脚台座）の幾何学的関 係から，フュジ一や木枠にどの程度の力が作用するの か計算した結果について報告する.

フュジ一受板と木枠の幾何学的な関係を図 8 に示す. ここで, 点 $\mathrm{O}$ から入力側フュジーの回転中心である 点 $\mathrm{A}$ までの長さが $88[\mathrm{~mm}]$, 点 $\mathrm{O}$ から出力側フ ユジーの回転中心である点 $\mathrm{B}$ までの長さが 56 $[\mathrm{mm}]$, 点 $\mathrm{O}$ からフュジ一受板側の柱受板受点で ある点 $\mathrm{C}$ の $x$ 成分 (点 $\mathrm{C}_{x}$ ) の長さが $37[\mathrm{~mm}]$, 点 $\mathrm{O}$ から点 $\mathrm{C}$ の $y$ 成分 (点 $\mathrm{C}_{y}$ ) の長さが $54[\mathrm{~mm}]$ である. 今, 点 $\mathrm{O}$ に対して対称な力が作用する場 合を考えると, 点 A において, フュジ一受板を回転 させようとする力 $F_{\mathrm{A} x}$ は, 次式のように表せる.

$$
F_{\mathrm{A} x}=\frac{\overline{\mathrm{OB}}}{\overline{\mathrm{AB}}} F_{\mathrm{A}}=0.537 F_{\mathrm{A}}
$$

この回転力の反力が柱受板に作用するので，木枠に作 用する力 $F_{\mathrm{D}}$ は, 次式のようになる.

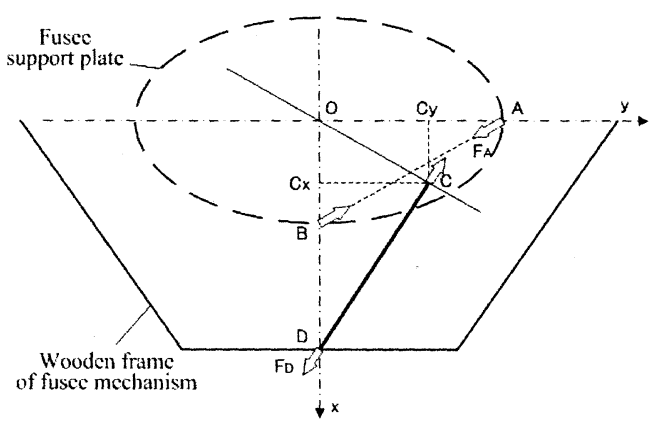

Fig. 8 Geometrical configuration of fusee support plate and wooden frame

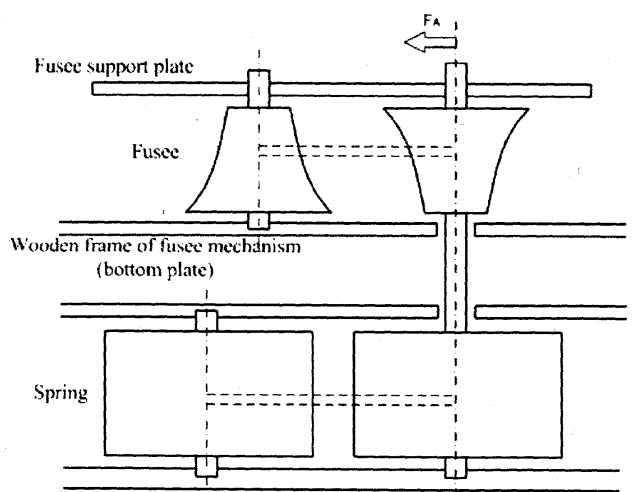

(a) Side view

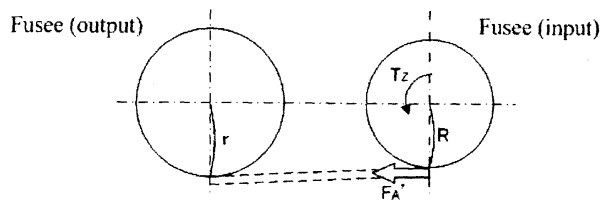

(b) Top view of fusee

Fig. 9 Cross section diagram of power supply

$$
F_{\mathrm{D}}=\frac{\overline{\mathrm{OA}}}{\overline{\mathrm{OC}}} F_{\mathrm{Ax}}=0.722 F_{\mathrm{A}}
$$

そして, 最終的に求めたい木枠に作用する引張り力 $F_{\mathrm{D} x}$ と剪断力 $F_{\mathrm{D} y}$ は, 次式のように求めることができる.

$$
\begin{aligned}
& F_{\mathrm{D} x}=\frac{\overline{\mathrm{OC}_{y}}}{\overline{\mathrm{OC}}} F_{\mathrm{D}}=0.596 F_{\mathrm{A}} \\
& F_{\mathrm{D} y}=\frac{\overline{\mathrm{OC}_{x}}}{\overline{\mathrm{OC}}} F_{\mathrm{D}}=0.408 F_{\mathrm{A}}
\end{aligned}
$$

次にゼンマイの発生トルクから入力側フュジ一の回 転中心に作用寸る力 $F_{\mathrm{A}}$ を求める. フュジ一受板, フュ ジ一，ゼンマイは，図9のような位置関係にあり，ゼ ンマイにより発生する力 $F_{\mathrm{A}}^{\prime}$ は, フュジ一間に働く引張 
り力 $F_{\mathrm{A}}$ とほぼ等しいと考えられる.ゼンマイの最大巻 き角度を $\Omega$, ゼンマイの解放角を $\alpha$, ゼンマイの単位 角度当たりのトルクを $M_{0}$ とすると，ゼンマイのトル ク $T_{Z}$ は, 次式のように表せる.

$$
T_{Z}=M_{0}(\Omega-\alpha)
$$

これより,力 $F_{\mathrm{A}}^{\prime}$ は, 次式のように求めることができる.

$$
F_{\mathrm{A}}^{\prime} \cong \frac{T_{Z}}{R}
$$

ここで, ゼンマイの巻き数を $N$ として, ゼンマイを $N$ 回巻いた初期状態 $(\alpha=0)$ を考えると, 式 (4) は次 式となる.

$$
F_{\mathrm{A}}^{\prime} \cong \frac{2 \pi M_{0}}{R_{N}} N
$$

ゼンマイのトルク測定値（3 節, 図 12 参照）より,

$$
M_{0} \cong 1450[\mathrm{kgfmm}]=14.2[\mathrm{Nm}]
$$

を用いると，ゼンマイを 1 回巻いたとき $(N=1)$ ，測 定結果より $R_{l}=29.3[\mathrm{~mm}]$ であるから, 力 $F_{\mathrm{A}}^{\prime}$ の值は以下 のように計算される.

$$
F_{\mathrm{A}, N=1} \cong 311[\mathrm{kgf}]=3.05 \times 10^{3}[\mathrm{~N}]
$$

この結果を式（1）及び（2）に代入すると, 引張り力 $F_{D x}$ と剪断力 $F_{D y}$ は, 以下のように求まる.

$$
\begin{aligned}
& F_{\mathrm{D} x} \cong 185[\mathrm{kgf}]=1.82 \times 10^{3}[\mathrm{~N}] \\
& F_{\mathrm{D} y} \cong 127[\mathrm{kgf}]=1.24 \times 10^{3}[\mathrm{~N}]
\end{aligned}
$$

ゼンマイを 1 回巻いただけでも，かなり大きな力が 木枠に働くことがわかる.木枠の強度は不明であるが, 実際の万年時計の木枠などには亀裂が入っており，ゼ ンマイを巻いたとき大きな力が働いて，発生したもの と考えられる.このことから，実際にはゼンマイをた くさん巻くことが出来なかったのではないかと推定で きる.

\section{3. ゼンマイ}

本章では, 動力源であるゼンマイの詳細について, 調査した結果を報告する.

3-1 形状と材料 現在, 万年時計に装着されて いるゼンマイは, 3 代目であると考えられている. 初 代のゼンマイは，田中久重が刀匠に依頼して打たせた ゼンマイであり, 2 代目のゼンマイは, 明治 17 年 (1884 年）に二代目田中久重が初代久重門弟の田中精助に依 頼して万年時計を分解調査した際，ゼンマイに亀裂が 入っていたために交換したものである. 3 代目のゼン
マイは, 昭和 24 年（1949 年）に東京科学博物館の朝 比奈貞一らにより行われた万年時計の分解調查におい て，交換されたものである.このときも，ゼンマイに 亀裂が入っていたため, 同質のものを製作し交換した. ゼンマイが交換されたという記述 ${ }^{(10)}$ は，この二回以外 にはないため, 現在 3 代目のゼンマイが万年時計に装 着されていると考えられる. 3 代目ゼンマイの写真を 図 10 に示す.

今回の調査でこの 3 代目ゼンマイの寸法測定及び材 料分析を行った. その結果を表 2 に示寸. また, 表 2 のゼンマイ寸法值から, ゼンマイの有効巻数が約 3.8 [回］程度であることが求まる(7).

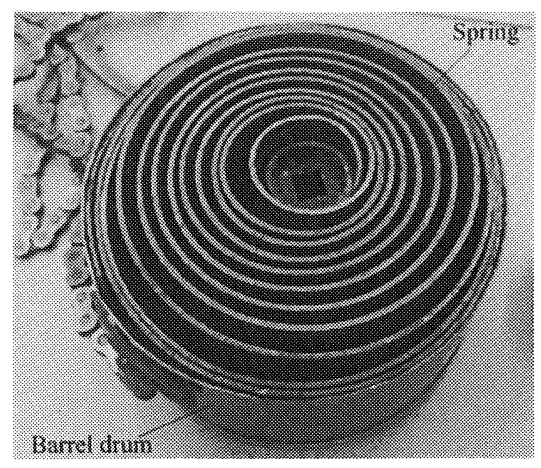

Fig. 10 Spring (output spring for driving, $3^{\text {rd }}$ generation)

Table 2 Size and material analysis of the spring

\begin{tabular}{|c|c|}
\hline Spring Length & $3050[\mathrm{~mm}]$ \\
\hline Spring Width & $65[\mathrm{~mm}]$ \\
\hline Spring Thickness & $1.9[\mathrm{~mm}]$ \\
\hline Barrel Diameter & $\phi 120.5[\mathrm{~mm}]$ \\
\hline Shaft Diameter & $\phi 27.0[\mathrm{~mm}]$ \\
\hline & $7-3$ Brass \\
Material & $(\mathrm{Cu}: 73.08 \%, \mathrm{Zn}: 26.20 \%, \mathrm{Sn}: 0.35 \%$, \\
& $\mathrm{Pb}: 0.15 \%, \mathrm{Fe}: 0.22 \%)$ \\
\hline
\end{tabular}

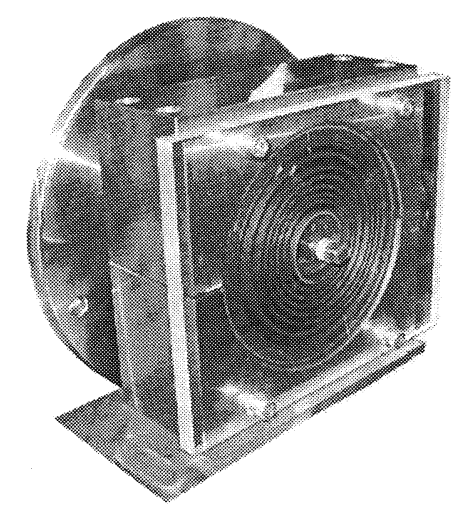

Fig. 11 Experimental setup for torque measurement 


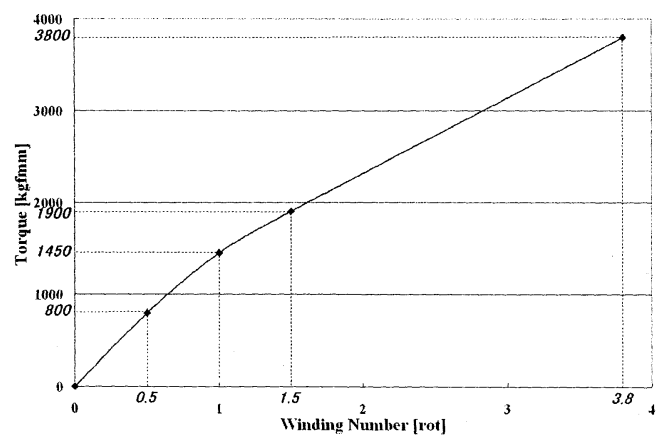

Fig. 12 Experimental result of spring torque

$3 \cdot 2$ トルク特性 次に, 3 代目ゼンマイのトルク の測定について述べる.トルク測定は図 11 に示すよう に，ゼンマイの香箱を固定し，解放した状態からゼン マイ軸を回転していき，ゼンマイを巻締めていく過程 の, 各回転数におけるトルクを測定した. トルクの測 定結果を図 12 に示す. 今回, 香箱の外側を補強して測 定実験を行ったが, $1 \mathrm{~mm}$ 厚しかない香箱の変形を危惧 し，実験は，1.5回転までとした.このため 1.5 回転以 上のトルクは推定值である. 前述したように，3 代目 ゼンマイの有効巻数は約 3.8 [回] であるので, 図 12 の結果では, 3.8 回転までのトルクを示してある.

\section{4. フュジ一機構}

ゼンマイが発生するトルクは, 巻かれた状態から解 けるときに大きく変動する.この変動を均一化するた めにフュジ一機構が考案された．通常，フュジ一機構 は断面が放物線に近いフュジーと円筒（ゼンマイを納 めた香箱の場合が多い)との組み合わせで構成される (図 13) (7). しかし，万年時計では図 6 や図 7 のよ に2個のフュジーを上下逆向きにして構成している. 本章では，フュジーを 2 個用いた万年時計の動力特性 を解析的に推定し，フュジーを2 個用いた理由につい て考察する.

4・1 万年時計動力部の特性 図 14 のようにゼン マイ側にもフュジ一が取り付けられている場合を考え る. 今, チェーンがゼンマイ側のフュジーの半径 $R(\alpha)$ の位置と出力側フュジ一の半径 $r(\beta)$ 位置に架かって いる時のことを考える. ゼンマイのトルクは, 式 (3) のように表わせるので，この時の出力軸に伝わるトル ク $T_{\text {out }}$ は,

$$
T_{\text {out }}=\frac{r}{R} M_{0}(\Omega-\alpha)
$$

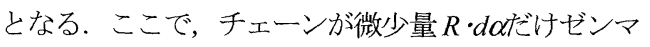
イ側のフュジ一から解放されると, 出力側フュジーに

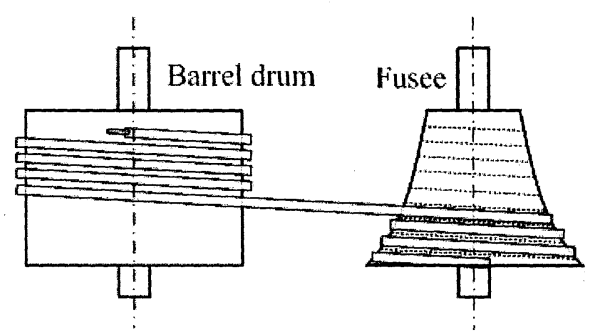

Fig. 13 Fusee and spring barrel composition

Fusee (input)

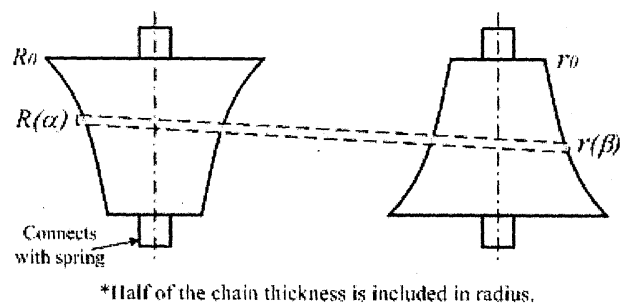

Fig. 14 Fusee composition of Man-nen dokei

同じ長さ $r \cdot d \beta か ゙$ 巻かれねばならないので

$$
\int_{0}^{\alpha} R(\alpha) d \alpha=\int_{0}^{\beta} r(\beta) d \beta
$$

が成り立つ.

今, ゼンマイの最大巻き数を $N$, ゼンマイが最大に 巻かれたときからのゼンマイ軸の回転数を $n$, 出力軸 の回転数を $m$ とすると

$$
\Omega=2 \pi N, \quad \alpha=2 \pi n, \quad \beta=2 \pi m
$$

と表せる. 式（8）を式（6），（7）に用いると次式の 関係を得る.

$$
\begin{aligned}
& T_{\text {out }}=2 \pi \frac{r(m)}{R(n)} M_{0}(N-n) \\
& \int_{0}^{n} R(n) d n=\int_{0}^{m} r(m) d m
\end{aligned}
$$

出力軸のトルク特性を求めるためには, $R(n)$ と $r(m)$ が 式（10）の関係を満たす条件のもとに式 (9) を計算す ればよい.

数式処理計算ソフトウエアの Mathematica (米 Wolfram Research Inc.の登録商標）を用いて，式 (9)， (10)より出力軸の特性を求めた. フュジ一の形状 $R(n)$, $n(m)$ は，表 2 の実測值を三次多項式で補完することに より求めた. 1 年連続稼動させるためにゼンマイ軸を 8 巻きした場合と現在残されている構成に近い 5 巻きし た場合について計算を行った. その結果を図 15 に実線 と点線で示す. 


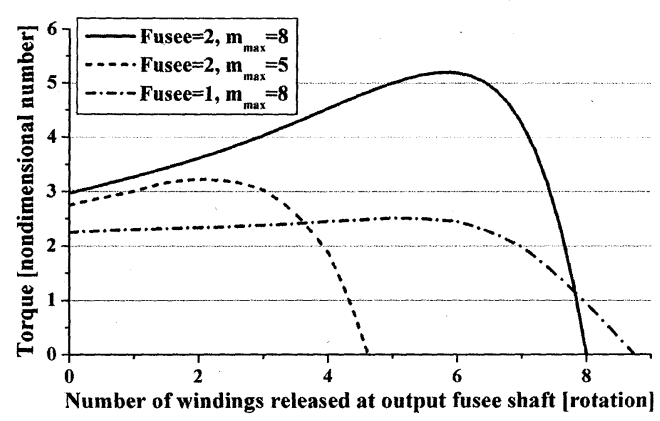

Fig. 15 Calculated results of spring output torque

4-2 フュジー2 個使いについての考察 ここでは, 田中久重が万年時計で何故フュジーを2 個使ったのか ということについて考察する. まず, フュジ一機構の 通常の構成である円筒とフュジーとの組み合わせで, どのような出力特性が得られるかについて仮想設計を 行う.フュジ一機構が収められている木枠 (六脚台座) 内に収まることを設計上の制約条件とした．具体的に は, 円筒の半径を $R_{0}$, フュジ一の最大半径を $r_{8}$ とし

$$
R_{0}+r_{8} \leq 70[\mathrm{~mm}]
$$

を制約条件とした.

出カトルクを一定とするフュジーの半径は次式によ り求められる

$$
r_{m}=\frac{r_{0}}{\sqrt{1-\frac{2 r_{0}}{R_{0}} \frac{m}{N}}}
$$

ここで, $r_{0}$ は実際のフュジーと同じ $12.3[\mathrm{~mm}]$ とする. また, 出力軸の回転数 $m$ の最大值は 1 年連続稼動を想 定して $m_{\text {max }}=8$ とする.

仮想設計を行うに当たり，木枠に大きな力が作用し ないようにゼンマイ軸の巻き数 $N を$ 極力小さくするこ とを考える. しかし， $N$ を小さすると式 (11) 右辺 の分母から $R_{0}$ を大きくする必要があり, 制約条件を満 たさなくなるため, ここでは $N=6$ として仮想設計を進 める. この場合, 出力軸が 8 回転したときにゼンマイ が全て解放されるとすると, 式（11）右辺の分母がゼ ロとなる条件より

$$
R_{0}=32.8[\mathrm{~mm}]
$$

を得る．したがって，制約条件より $r_{8}$ を $37.2[\mathrm{~mm}]$ まで大きくすることができる.

式 (11) より $r_{k}(k=1,2, \ldots, 7)$ を求めると以下のよう になる.

$$
\begin{aligned}
& r_{1}=13.1[\mathrm{~mm}] \\
& r_{2}=14.2[\mathrm{~mm}] \\
& r_{3}=15.6[\mathrm{~mm}] \\
& r_{4}=17.4[\mathrm{~mm}] \\
& r_{5}=20.1[\mathrm{~mm}] \\
& r_{6}=24.6[\mathrm{~mm}] \\
& r_{7}=34.8[\mathrm{~mm}]
\end{aligned}
$$

このフュジーの形状を三次多項式で補完し, 出力軸の トルク特性を計算すると図 15 の一点鎖線のようにな る. 図 15 が示すように, フュジ一機構の通常の構成で あるフュジー1 個使いの方が，不必要に大きな力を木 枠に作用させずに均一な出力トルクを得られ, 万年時 計の動力系としては適していることがわかる. したが って, 田中久重が, フュジーを 2 個使ったフュジー機 構を用いた理由は不明である.

\section{5. まとめ}

本論文では, 万年時計の動力部の機構解明及び考察 を行った. 動力部の機構構成から, 現存の万年時計の 最大連続可動日数が約 225 日であることがわかったが, フュジーの段数やゼンマイの二連化による駆動時間長 期化の工夫などから, 久重は 1 年連続可動を目標にし ていたと考えられる. 1 年連続可動できる動力部を目 指した結果, 巨大なトルクを発生するゼンマイが必要 となったが，木枠の強度不足により，実際にはゼンマ イを僅かしか巻くことができなかったと推定される. また, 1 年連続動作に必要なトルクを安定して得るに は, フュジー1 個の構成の方が合理的な設計が可能で あり, 久重が何故フュジー2 個の構成としたのかは不 明である。

\section{碀辞}

本研究を行うにあたり，セイコープレシジョン株式 会社およびサンコースプリング株式会社にご協力をい ただきました.ここに深謝の意を表します.

\section{文献}

(1) Y. Kubota, Mechanism of "Man-nen dokei," Toshiba Review, Vol. 6, No. 7(2005),pp. 116-119.

(2) M. Yoshida et al., Mechanism of the Man-nen dokei Part 1: Wadokei, Proceedings of JSME Mechanical Engineering Congress, Vol. 5(2005-9), pp. 51-52.

(3) Y. Yokota et al., Mechanism of the Man-nen dokei Part 2: Celestial globe, Proceedings of JSME Mechanical Engineering Congress, Vol. 5 (2005-9), pp. 53-54.

(4) T. Hato et al., Mechanism of the Man-nen dokei Part 3: Power supply, Proceedings of JSME Mechanical Engineering Congress, Vol. 5 (2005-9),pp. 55-56.

(5) H. Tanaka, Man-nen dokei design drawings, owned by National ScienceMuseum. 
(6) 3rd Hisashige Tanaka, Configuration of the Man-nen dokei, (1957).

(7) T. Aoki, Horology, Maruzen Co., (1938).

(8) K. Suzuki, "Mechanism Arts" Japanese Automata "KARAKURI," Journal of Japan Society for Design Engineering, Vol. 31, No. 2 (1996), pp. 4147.
(9) T.Asahina and S.Oda, "Myriad-Year Clock" Made by G.H.Tanaka 100 Years Ago in Japan, Bulletin of the Nationa Science Museum(Tokyo), Vol. 1, No.2 (1954).

(10) 3rd Hisashige Tanaka, History of the Man-nen dokei, (1960). 